\title{
LA EXTRACCIÓN DE ÓRGANOS DE DONANTES \\ VIVOS EN LA NUEVA LEY DE JURISDICCIÓN VOLUNTARIA
}

\author{
Organ Removal from Living Donors \\ in the New Voluntary Jurisdiction Act
}

\author{
JAVIER BARCELÓ DOMÉNECH \\ Universidad de Alicante \\ i.barcelo@va.es
}

Cómo citar/Citation

Barceló Doménech, J. (2016).

La extracción de órganos de donantes vivos

en la nueva Ley de Jurisdicción Voluntaria.

Derecho Privado y Constitución, 30, 221-256.

doi: http://dx.doi.org/10.18042/cepc/dpc.30.05

(Recepción: 11/08/2016; aceptación después de la revisión: 27/09/2016; publicación: 17/1 1/2016)

\section{Resumen}

La escasez crónica de órganos ha determinado que su donación por personas vivas — uno de los grandes avances de la Medicina - se convierta hoy en día en una importante fuente para los trasplantes (riñones, partes de hígado, pulmones, páncreas, intestinos, etc.). La donación en vida produce resultados superiores para el receptor en comparación con la donación post-mortem: tiempos de espera más cortos y mejor calidad de vida y de supervivencia en el receptor. Como consecuencia de sus acreditadas ventajas, muchos países han admitido la donación en vida, que es asimismo considerada como moralmente aceptable. En España, la nueva Ley de Jurisdicción Voluntaria de 2015 regula el expediente de extracción de órganos de personas vivas. La ley española establece, al igual que las regulaciones de otros países, que la declaración del consentimiento del donante sea formulada bajo supervisión y con aprobación de un juez; esta intervención judicial se dirige esencialmente a garantizar 
el consentimiento del donante libre, informado y desinteresado. Este trabajo es un estudio sobre este caso de jurisdicción voluntaria.

\section{Palabras clave}

Donación de órganos y trasplante; donante vivo; jurisdicción voluntaria.

\section{Abstract}

The chronical shortage of organs has made that living organ donation (LOD) - one of greatest advances in medical history - emerges as an important source of trasplant (kidneys, parts of liver, lungs, pancreas, intestines, etc.). LOD produces superior outcomes for the recipient compared to the diseased donation: shorter waiting times, better recipient survival and quality of life. As a result of its demostrated advantages, many countries have implemented LOD, that is also considered as morally justified. In Spain, the new Voluntary Jurisdiction Act of 2015 regulates the proceeding to extract organs from living donors. Spanish law provides, like that of other countries, that the statement of the donor's consent should be formulated under the supervision and with the approval of a Judge; this judicial intervention is intended substantially to ensure the free, informed and non-profit donor's consent. This paper studies this case of voluntary jurisdiction.

\section{Keywords}

Organ donation and transplantation; living donor; voluntary jurisdiction. 


\section{SUMARIO}

I. INTRODUCCIÓN: LA EXPANSIÓN DE LA DONACIÓN DE ÓRGANOS DE PERSONAS VIVAS. II. DONACIÓN DE ÓRGANOS Y DERECHO A LA INTEGRIDAD FÍSICA. LA LEY 30/1979, DE 27 DE OCTUBRE, SOBRE EXTRACCIÓN Y TRASPLANTE DE ÓRGANOS, Y NORMATIVA COMPLEMENTARIA. III. REQUISITOS PARA LA OBTENCIÓN DE ÓRGANOS DE DONANTE VIVO. IV. REGULACIÓN DEL EXPEDIENTE JUDICIAL EN LA NUEVA LEY DE JURISDICCIÓN VOLUNTARIA: 1. Ámbito de aplicación; 2. Competencia: 2.1. Competencia objetiva; 2.2. Competencia territorial; 3. Solicitud: 3.1. Legitimación para instar el expediente; 3.2. Representación y defensa; 3.3. La iniciación del expediente: solicitud o comunicación; 4. Admisión de la solicitud y citación de los interesados: 4.1. El Ministerio Fiscal; 4.2. El receptor del órgano; 5. Comparecencia; 6. Resolución; 7. Recursos. V. BIBLIOGRAFÍA.

\section{INTRODUCCIÓN: LA EXPANSIÓN DE LA DONACIÓN DE ÓRGANOS DE PERSONAS VIVAS}

Desde principios de los años cincuenta del pasado siglo, el trasplante de órganos ha sido una de las áreas de mayor desarrollo en la ciencia médica, con excelentes resultados de supervivencia y calidad de vida ${ }^{1}$. El éxito del trasplante se ha visto, sin embargo, empañado por la existencia de listas de espera, siendo la escasez de órganos uno de los mayores desafíos que se presentan en la actualidad. En este contexto, dado el fracaso en satisfacer la creciente demanda a través de donantes fallecidos, se ha recurrido cada vez más a la donación de órganos de personas vivas ${ }^{2}$.

1 Sobre la historia de esta técnica, en sus aspectos generales, véase Arroyo y Fernández (1987: 1871).

2 Sobre este planteamiento, véase Lennerling et al. (2013: 10).

El propio marco legal de la donación de órganos de personas vivas puede, si sus principios no son adecuados, crear una «escasez artificial». Hace casi veinte años, Evans (1997: 19) se refería a una enfermedad que sufría Europa en el campo de estas donaciones, a la que denominaba legislación altamente inapropiada: HIL (Highly Inappropiate Legislation). 
Este hecho ha sido expresamente reconocido por la Directiva 2010/45/ UE del Parlamento Europeo y del Consejo, sobre normas de calidad y seguridad de los órganos humanos destinados al trasplante, cuyo considerando 23 indica que «la donación en vida coexiste con la donación tras el fallecimiento en la mayoría de los Estados miembros», añadiendo que debe hacerse "de modo que se minimice el riesgo físico, psicológico y social para cada donante y receptor y que no comprometa la confianza pública en el sistema sanitario» ${ }^{3}$.

Así, pues, la donación de órganos de personas vivas (living organ donation, en adelante LOD) es vista como una valiosa alternativa para dar solución a la escasez de órganos ${ }^{4}$. Destaca el proyecto EULOD (Living Organ Donation in Europe), impulsado por la Comisión Europea, que empezó en 2010 y concluyó en 2012, con la intención de realizar un inventario de las prácticas en los diferentes países europeos, explorar y promover la donación de órganos de personas vivas como una vía para incrementar la disponibilidad de órganos, y presentar recomendaciones para mejorar la calidad y seguridad. Los ciudadanos europeos, en situación de necesidad de trasplante de un órgano, deberían tener igualdad de acceso a LOD, siendo deseable una armonización de los ordenamientos, algo perfectamente posible a la vista de otras iniciativas en el ámbito del derecho privado5.

En España, el balance de actividad de $2015^{6}$, presentado por la Organización Nacional de Trasplantes (en adelante, ONT), informa que nuestro

3 La relación entre donación en vida y donación post-mortem se establece, sin embargo, en términos de subsidiariedad, acudiéndose a la primera cuando no es posible la segunda. Es la conclusión que cabe extraer de la lectura del art. 19.2 del Convenio para la protección de los derechos humanos y la dignidad del ser humano con respecto a las aplicaciones de la biología y la medicina (hecho en Oviedo el 4 de abril de 1997, Instrumento de Ratificación BOE de 20 de octubre de 1999), y del art. 9 del Protocolo Adicional al Convenio relativo a los derechos humanos y la biomedicina sobre el trasplante de órganos y de tejidos de origen humano (hecho en Estrasburgo el 24 de enero de 2002, Instrumento de Ratificación, BOE de 29 de enero de 2015).

4 Sobre esta circunstancia, y sobre las ventajas que representa la donación de órganos de persona viva para el receptor (en particular, la menor tasa de mortalidad), véase Pascalev et al. (2013: 28).

5 Al respecto, Lopp (2013b: 108).

Interesa señalar que la Carta de Derechos Fundamentales de la Unión Europea destaca, en particular, que una prohibición o restricción injustificada de la donación de órganos de personas vivas entraría en conflicto con los arts. 2.1 («Toda persona tiene derecho a la vida»), 3.1 («Toda persona tiene derecho a su integridad física y psíquica») y 35 (protección de la salud) de la Carta. Al respecto, Lopp (2013b: 125).

6 Disponible en www.msssi.es. 
país, líder mundial de donaciones desde hace veinticuatro años, amplía la distancia con el resto del mundo al acercarse a los cuarenta donantes por millón de habitantes. Este dato, que incluye tanto al donante vivo como al fallecido, sirve para darnos cuenta de la generosidad de los ciudadanos y la implicación de los profesionales de toda la red trasplantadora. Sirve también esta fortaleza del sistema español de trasplantes para poner de manifiesto la importancia de contrastar la eficacia del marco jurídico que canaliza la obtención del consentimiento libre y suficientemente informado del donante vivo, que va ser objeto de nuestro estudio.

\section{DONACIÓN DE ÓRGANOS Y DERECHO A LA INTEGRIDAD FÍSICA. LA LEY 30/1979, DE 27 DE OCTUBRE, SOBRE EXTRACCIÓN Y TRASPLANTE DE ÓRGANOS, Y NORMATIVA COMPLEMENTARIA}

Desde la óptica civilista ${ }^{7}$, el foco de atención en el delicado problema de la extracción y trasplante de órganos se ha puesto en el derecho fundamental a la integridad física y en la objetiva lesión que padece quien cede un órgano de su cuerpo para ser trasplantado a otra persona.

En este sentido, se ha dicho que el derecho a la integridad física, proclamado por el art. $15 \mathrm{CE}$, no impide la práctica de la obtención y utilización clínica - especialmente trasplantes - de órganos humanos, siempre que sea realizada bajo determinadas condiciones y dentro de unos márgenes estrictos y tipificados legalmente ${ }^{8}$. Este es un caso en que se admite cierto poder de

7 Es la aproximación técnico-jurídica tradicional de la doctrina, que trata el tema dentro de los derechos de la personalidad: por todos, Albaladejo (2009: 472).

8 En el ámbito civil, señalan Lacruz et al. (2010:72), venía entendiéndose que existe cierto margen y facultad de disposición sobre partes separables del cuerpo dentro de unos límites que no contraríen la moral, las buenas costumbres y el orden público, y en este sentido, se entendían permitidas — aun sin acuerdo unánime — la venta de los propios cabellos o de la leche materna (contrato de «ama de cría»); luego, las donaciones de sangre, cuando esta fuera útil para las transfusiones o, con mayores dudas, la de semen, para inseminación artificial en ambiente médico.

Una vez admitida la extracción de órganos para su trasplante a otra persona, no es extraño, como indica Angoitia Gorostiaga (2011: 1636), que se rodee de los más cualificados requisitos que garanticen la plena conciencia y libertad de quien decide actuar en tal sentido, traducidos en lo que ha venido a denominarse, con carácter general, "consentimiento informado», que, en la cirugía sustitutiva alcanza, posiblemente, su más paradigmática manifestación. 
disposición sobre la integridad corporal como ejercicio de un derecho de la personalidad?.

La regulación se encuentra en la Ley 30/1979, de 27 de octubre, sobre Extracción y Trasplante de Órganos (en adelante, LETO) ${ }^{10}$, posteriormente desarrollada a nivel reglamentario ${ }^{11}$, concretamente por el Real Decreto 1723/2012, de 28 de diciembre, por el que se regulan las actividades de obtención, utilización clínica y coordinación territorial de los órganos humanos destinados al trasplante y se establecen requisitos de calidad y seguridad.

No es incompatible con el derecho a la integridad física por la voluntariedad de la cesión de órganos y los principios que la rigen: el trasplante de órganos se realiza con fines terapéuticos y en centros especialmente autorizados para ello; se parte de la idea de que se trata de una donación, prohibiendo expresamente que exista compensación económica alguna para el donante, de manera que se evite un comercio de órganos humanos; y se dedica especial atención al consentimiento del donante, regulando detalladamente la forma de prestarlo y las condiciones en que ha de hacerse ${ }^{12}$.

La legislación española prevé la intervención judicial para obtener el consentimiento del donante vivo, a través de la jurisdicción voluntaria.

9 Acerca de la naturaleza del derecho sobre las partes separadas del cuerpo humano, véase, entre otros, López (1969: 148) y Gordillo (1987: 39).

10 Sobre el contexto histórico en que se publica la LETO y la situación anterior legal (Ley de 18 de diciembre de 1950, que por primera vez reguló en nuestro ordenamiento la obtención de piezas anatómicas de fallecidos para injerto o trasplante en otras personas), véase Romeo Casabona (1982: 784-992).

11 Una de las notas que caracterizan la Ley 30/1979, a juicio de Romeo Casabona (1982:792), es su sencillez, puesto que en esencia solo procede a una declaración de principios y de garantía de los bienes jurídicos implicados, dejando todos los aspectos técnicos y de procedimiento al Reglamento de ejecución de la Ley y demás disposiciones complementarias, con lo cual se garantiza mayor estabilidad y permanencia de su eficacia.

12 Es un principio básico, tal y como se señala en el considerando 23 de la exposición de motivos de la Directiva 2010/45/UE del Parlamento Europeo y del Consejo de 7 de julio: «El posible donante vivo tiene que poder decidir libremente sobre la base de toda la información pertinente, y debe ser informado de antemano sobre la finalidad y la naturaleza de la donación, sus consecuencias y sus riesgos. En este contexto, y para garantizar el respeto de los principios por los que se rige la donación, debe garantizarse la mayor protección posible de los donantes vivos».

Ciertamente, como apunta Ruiz (1989:348), los problemas que plantea este tipo de trasplantes de donantes vivos giran básicamente en torno al consentimiento, siendo preciso fijar claramente qué requisitos son necesarios para que el consentimiento pueda considerarse válido. 
Inicialmente, el art. 4 c) LETO dispone que el consentimiento del donante se manifieste «ante la autoridad pública que reglamentariamente se determine». El primer reglamento de desarrollo, que fue el Real Decreto 426/1980, de 22 de febrero, señaló en su art. 4.I que dicha autoridad era «el juez wncargado del Registro Civil de la localidad de que se trate», atribución que se mantuvo en los mismos términos en el segundo reglamento, concretamente en el art. 9.4.I del Real Decreto 2070/1999, de 30 de diciembre. Sin embargo, el tercer reglamento de desarrollo, el Real Decreto 1723/2012, de 28 de diciembre, cambia la competencia, que pasa, según el art. 8.4.I, al «juzgado de primera instancia de la localidad donde haya de realizarse la extracción o el trasplante».

Ahora bien, las normas procedimentales del Real Decreto 1723/2012, que es el actualmente vigente, se ven afectadas por la nueva Ley de Jurisdicción Voluntaria.

Tras un proyecto infructuosamente tramitado entre los años 2005 y 2007, el 3 de julio de 2015 se publicó en el Boletín Oficial del Estado la Ley 15/2015, de 2 de julio, de Jurisdicción Voluntaria (en adelante, LJV), que da cumplimiento, tras más de quince años, al mandato contenido en la Ley 1/2000, de 7 de enero, de Enjuiciamiento Civil, cuya disposición final decimoctava establecía la obligación del Gobierno de remitir a las Cortes Generales un Proyecto de Ley sobre Jurisdicción Voluntaria en el plazo de un año.

Desde el punto de vista procesal, los títulos preliminar y primero de la LJV contemplan un procedimiento único para todos los expedientes que se tramiten por vía judicial, si bien en los sucesivos apartados de la ley se prevén trámites específicos para los diversos expedientes regulados.

Uno de los expedientes que se han regulado en la nueva LJV y concretamente en materia de personas (título II), es el relativo a la intervención judicial en los casos de extracción de órganos de donante vivo. A pesar de su aparente simplicidad, hay algunas cuestiones ciertamente controvertidas que no tienen una solución específica en la nueva normativa, provocando dudas interpretativas la falta de precisión del legislador; es el caso, por ejemplo, de la oposición que los médicos pueden eventualmente plantear en el trámite de la comparecencia.

Para garantizar la libre y consciente expresión del consentimiento del donante, la LJV de 2015 instituye un procedimiento de jurisdicción voluntaria $^{13}$. No constituye, sin embargo, una novedad, en tanto que, como ya se

13 Juan Sánchez (2015: 86) define la jurisdicción voluntaria de los tribunales como «aquella intervención de los mismos, autorizada por ley y con fundamento general en el artículo 117.4 CE, destinada, siguiendo las formas propias de un proceso, a 
ha visto, el art. 4.c) de la Ley 30/1979, de 27 de octubre, sobre extracción y trasplante de órganos, y el art. 8, números 4 y 5, del Real Decreto 1723/2012, de 28 de diciembre, por el que se regulan las actividades de obtención, utilización clínica y coordinación territorial de los órganos humanos destinados al trasplante, preveían este mismo procedimiento.

La doctrina ha puesto de manifiesto que se trata de un expediente de jurisdicción voluntaria de naturaleza homologadora, ya que con su actuación el juez no constituye un estado jurídico, sino que comprueba que tanto el donante como la propia donación cumplen todos los requisitos legales exigidos para que la cesión del órgano se lleve a cabo sin riesgos para la salud del donante y sin verse contrariadas la moral, las buenas costumbres y el orden público $^{14}$. A mi juicio, es importante destacar que el consentimiento del donante es necesario, pero no es suficiente para justificar la extracción del órgano; hay una serie de requisitos adicionales que deben cumplirse, se entiendan o no en términos de autorización, y debe intervenir el juez ${ }^{15}$. La presencia del juez y del cuadro médico-hospitalario, junto con la posibilidad de no otorgar el documento de cesión o de oponerse si se albergan dudas, constituyen cualificados requisitos, plenamente justificados al tratarse de intervenciones de riesgo.

Finalmente, cabe indicar que el estudio del expediente de jurisdicción voluntaria va a plantear prácticamente todas las cuestiones que rodean a la donación de órganos por personas vivas: el consentimiento informado ${ }^{16}$, la idoneidad para el trasplante, la situación del menor de edad en cuanto donante, la relación entre donante y receptor, las reglas procedimentales y las prestaciones de la Seguridad Social.

constituir, autorizar, homologar, documentar o simplemente presenciar una relación o situación jurídica privada y sin que se produzcan los efectos propios de la cosa juzgada».

14 Es el planteamiento de Liébana y Pérez (2015: 329).

15 Se aparta así el sistema español del austríaco, alemán, holandés y suizo, en el que basta el consentimiento del donante si fue suficientemente informado. Al respecto, Lopp (2013b: 110).

El derecho portugués también presenta diferencias con el español. La regulación actual, que es la de la Ley 22/2007, de 22 de abril, dispone, en su art. 6 la necesidad, en caso de donación en vida de órganos o tejidos no regenerables, del dictamen favorable de la Entidade de Verificação da Admissibilidade da Colheita para Trasplante (EVA); ahora bien, se exige autorización judicial si se trata de extranjeros sin residencia permanente en Portugal.

16 Este es un caso de consentimiento informado en una situación especial, con su propia regulación específica (LETO, Real Decreto 1723/2012 y LJV). 
Una última consideración se hace también necesaria. Las referencias jurisprudenciales se contienen en los expedientes de jurisdicción voluntaria de los jueces de primera instancia. No hay (o al menos, no nos consta) sentencias de audiencias o del Tribunal Supremo en esta materia, y la razón es bien clara: al no plantearse recurso frente al expediente, no ha lugar a la intervención de tribunales superiores.

\section{REQUISITOS PARA LA OBTENCIÓN DE ÓRGANOS DE DONANTE VIVO}

En la Ley 30/1979, de 27 de octubre, se regulan los requisitos por los que se autoriza, con fines terapéuticos, «la cesión, extracción, conservación, intercambio y trasplante de órganos humanos» (art. 1). No se puede percibir compensación alguna (art. 2) ${ }^{17}$ y la extracción solamente puede realizarse en centros autorizados (art. 3). Cuando el donante es una persona viva, el art. 4 exige una serie de requisitos para permitir la donación: básicamente que el donante sea mayor de edad y pueda prestar un consentimiento informado. Cuando ya ha fallecido, basta con que no conste su oposición (art. 5). También el receptor debe prestar su consentimiento informado acerca de la intervención (art. 6) ${ }^{18}$.

17 La prohibición de compensación económica, dicen Díez-Picazo y Gullón (2012: 333), «significa la inadmisibilidad de los negocios a título oneroso que tengan por objeto órganos humanos, aunque nada impide que el receptor, como expresión de agradecimiento, realice una donación de algo, pues ello es situación que ninguna ley puede impedir». En la misma línea argumental, Lacruz et al. (2010: 74) entienden que «un gesto de agradecimiento del receptor, incluso con alguna donación por su parte al donante del órgano trasplantado, no desnaturaliza la calidad de donación de este último (todo lo más, habrá dos donaciones cruzadas), ni es la 'compensación económica' prohibida por la ley».

18 Requiere, pues, explícitamente la LETO el consentimiento del receptor; concretamente se dice en el art. 6 c): "Que el receptor exprese por escrito u otro medio adecuado a su discapacidad, su consentimiento para la realización del trasplante cuando se trate de un adulto jurídicamente responsable de sus actos, o por sus representantes legales, padres o tutores, si estuviera incapacitado o en caso de menores de edad. En el caso de que el receptor sea una persona con discapacidad, deberán tenerse en cuenta las circunstancias personales del individuo, su capacidad para tomar dicha decisión en concreto y contemplarse la prestación de apoyo para la toma de estas decisiones. Tratándose de personas con discapacidad con necesidades de apoyo para la toma de 
La distinción fundamental se establece, pues, entre donantes vivos y fallecidos, interesando a los efectos de este trabajo el primer caso.

Para la extracción y trasplante de órganos de personas vivas, el art. 4 de la Ley 30/1979 (modificado por la Ley 26/2011, de 1 de agosto, de adaptación normativa a la Convención Internacional sobre los Derechos de las Personas con Discapacidad), exige el cumplimiento de los siguientes requisitos ${ }^{19}$ :

a) Que el donante sea mayor de edad.

b) Que el donante goce de plenas facultades mentales y haya sido previamente informado de las consecuencias de su decisión. Esta información se referirá a las consecuencias previsibles de orden somático, psíquico y psicológico, a las eventuales repercusiones que la donación pueda tener sobre su vida personal, familiar y profesional, así como a los beneficios que con el trasplante se espera haya de conseguir el receptor.

c) Que el donante otorgue su consentimiento de forma expresa, libre y consciente, debiendo manifestarlo por escrito ante la autoridad pública que reglamentariamente se determine, tras las explicaciones del médico que ha de efectuar la extracción, obligado este también a firmar el documento de cesión del órgano. En ningún caso podrá efectuarse la extracción sin la firma previa de este documento. No podrá obtenerse ningún tipo de órganos de personas que, por deficiencias psíquicas o enfermedad mental o por cualquier otra causa, no puedan otorgar su consentimiento expreso, libre y consciente.

d) Que el destino del órgano extraído sea su trasplante a una persona determinada, con el propósito de mejorar sustancialmente su esperanza o sus condiciones de vida, garantizándose el anonimato del receptor.

e) Si el donante fuese una persona con discapacidad, la información y el consentimiento deberán efectuarse en formatos adecuados, siguiendo las reglas marcadas por el principio del diseño para todos, de manera que resulten accesibles y comprensibles a su tipo de discapacidad.

Estas previsiones de la Ley 30/1979 se complementan por el art. 8 del Real Decreto 1723/2012, de 28 de diciembre. Este art. 8 contiene una regulación detallada, que podemos esquematizar del siguiente modo: requisitos generales de

decisiones, se estará a la libre determinación de la persona una vez haya dispuesto de los apoyos y asistencias adecuados a sus concretas circunstancias».

19 La idea motriz es el altruismo y la solidaridad que deben caracterizar las relaciones sociales y que conllevan la permisividad y licitud de la cesión de órganos, siempre que se respeten estas disposiciones legales. Sobre el particular, Lasarte Álvarez (2015: 159). 
la donación; garantías de actuación médica previas al trámite judicial; mecánica del expediente de jurisdicción voluntaria; y disposiciones varias.

Se desarrollan en el núm. 1 los requisitos de la donación de órganos de personas vivas ya vistos a propósito del art. 4 de la Ley 30/1979:

a) El donante debe ser mayor de edad, gozar de plenas facultades mentales y de un estado de salud adecuado.

b) Debe tratarse de un órgano, o parte de él, cuya obtención sea compatible con la vida y cuya función pueda ser compensada por el organismo del donante de forma adecuada y suficientemente segura20.

c) El donante habrá de ser informado previamente de las consecuencias de su decisión, de los riesgos para sí mismo o para el receptor, así como de las posibles contraindicaciones, y de la forma de proceder prevista por el centro ante la contingencia de que una vez se hubiera extraído el órgano, no fuera posible su trasplante en el receptor al que iba destinado. El donante debe otorgar su consentimiento de forma expresa, libre, consciente y desinteresada. La información y el consentimiento deberán efectuarse en formatos adecuados, siguiendo las reglas marcadas por el principio de diseño para todos, de manera que resulten accesibles y comprensibles a las personas con discapacidad.

d) El donante no deberá padecer o presentar deficiencias psíquicas, enfermedad mental o cualquier otra condición por la que no pueda otorgar su consentimiento en la forma indicada. Tampoco podrá realizarse la obtención de órganos de menores de edad, aun con el consentimiento de los padres o tutores.

e) El destino del órgano obtenido será su trasplante a una persona determinada con el propósito de mejorar sustancialmente su pronóstico vital o sus condiciones de vida ${ }^{21}$.

Los números 2 y 3 del art. 8 hacen puntual referencia a una serie de actuaciones médicas que son previas al trámite judicial, básicamente la selección del donante y la acreditación de su estado de salud ${ }^{22}$. Se señala en el

20 Así, tal y como señalan Lacruz et al. (2010: 73), «no cabría el permiso o el consentimiento para dar a otro órganos únicos imprescindibles para la vida (el corazón)».

21 Esta norma, a juicio de Ibáñez Molinero (2015: 3), impide la creación de «bancos de órganos».

22 Esta regulación de los números 2 y 3 del art. 8 prevé, pues, una serie de garantías en el ámbito médico previo al expediente judicial de jurisdicción voluntaria. Por un lado, la preceptiva emisión de un informe del comité de ética correspondiente; por otro, un examen sobre la salud físico y mental del donante, realizado por médico cualificado, 
8.2.I que «no se obtendrán ni utilizarán órganos de donantes vivos si no se esperan suficientes posibilidades de éxito del trasplante, si existen sospechas de que se altera el libre consentimiento del donante a que se refiere este artículo, o cuando por cualquier circunstancia pudiera considerarse que media condicionamiento económico, social, psicológico o de cualquier otro tipo", añadiendo el art. 8.2.II que «en cualquier caso, para proceder a la obtención, será preceptivo disponer de un informe del comité de ética correspondiente». Por otro lado, hay puntuales indicaciones sobre la selección del donante en el art. 8.3.I: «Los donantes se seleccionarán sobre la base de su salud y sus antecedentes clínicos. El estado de salud físico y mental del donante deberá ser acreditado por un médico cualificado distinto de aquellos que vayan a efectuar la extracción y el trasplante, que informará sobre los riesgos inherentes a la intervención, las consecuencias previsibles de orden somático o psicológico, las repercusiones que pueda suponer en su vida personal, familiar o profesional, así como los beneficios que se esperan del trasplante y los riesgos potenciales para el receptor. En este sentido, debe trasladarse al donante vivo la importancia que reviste la transmisión de sus antecedentes personales. A la luz del resultado de este examen, se podrá excluir a cualquier persona cuando la obtención pueda suponer un riesgo inaceptable para su salud, o el trasplante del órgano obtenido para la del receptor», concretando el art. 8.3.II que «los anteriores extremos se acreditarán mediante un certificado médico que hará necesariamente referencia al estado de salud, a la información facilitada y a la respuesta y motivaciones libremente expresadas por el donante y, en su caso, a cualquier indicio de presión externa al mismo. El certificado incluirá la relación nominal de otros profesionales que puedan haber colaborado en tales tareas con el médico que certifica».

Los apartados 4 y 5 del art. 8 del Real Decreto 1723/2012 contienen una regulación del procedimiento de jurisdicción voluntaria en esta materia, que es sustancialmente idéntica a la de la LJV, tal y como se verá más adelante. $\mathrm{El}$ art. 8.4 se refiere a la solicitud y comparecencia en los siguientes términos: «Para proceder a la obtención de órganos de donante vivo, se precisará la presentación, ante el juzgado de primera instancia de la localidad donde ha de realizarse la extracción o el trasplante, a elección del promotor, de una

que debe ser distinto de aquellos que vayan a efectuar la extracción y el trasplante; y finalmente, la información al donante sobre los riesgos inherentes a la intervención, las consecuencias previsibles de orden somático o psicológico, las repercusiones que pueda suponer en su vida personal, familiar o profesional, así como los beneficios que se esperan del trasplante y los riesgos potenciales para el receptor. 
solicitud del donante o comunicación del director del centro sanitario en que vaya a efectuarse, o la persona en quien delegue, en la que se expresarán las circunstancias personales y familiares del donante, el objeto de la donación, el centro sanitario en que ha de efectuarse la extracción, la identidad del médico responsable del trasplante y se acompañará el certificado médico sobre la salud mental y física del donante» (art. 8.4.I); «El donante deberá otorgar su consentimiento expreso ante el juez durante la comparecencia a celebrar en el expediente de jurisdicción voluntaria que se tramite, tras las explicaciones del médico que ha de efectuar la extracción y en presencia del médico al que se refiere el apartado 3 de este artículo, el médico responsable del trasplante y la persona a la que corresponda dar la conformidad para la intervención, conforme al documento de autorización para la extracción de órganos concedida» (art. 8.4.II). A la resolución del expediente atiende el art. 8.5, conforme al cual «el documento de cesión del órgano donde se manifiesta la conformidad del donante será extendido por el juez y firmado por el donante, el médico que ha de ejecutar la extracción y los demás asistentes. Si alguno de los anteriores dudara que el consentimiento para la obtención se hubiese otorgado de forma expresa, libre, consciente y desinteresada, podrá oponerse eficazmente a la donación. De dicho documento de cesión se facilitará copia al donante. En ningún caso podrá efectuarse la obtención de órganos sin la firma previa de este documento».

Finalmente, encontramos tres disposiciones de variado contenido: «Entre la firma del documento de cesión del órgano y la extracción del mismo deberán transcurrir al menos veinticuatro horas, pudiendo el donante revocar su consentimiento en cualquier momento antes de la intervención sin sujeción a formalidad alguna. Dicha revocación no podrá dar lugar a ningún tipo de indemnización» (art. 8.6) ${ }^{23}$; «La obtención de órganos procedentes de donantes vivos solo podrá realizarse en los centros sanitarios expresamente autorizados para ello, debiendo informar del procedimiento a la autoridad competente responsable con anterioridad a su realización» (art. 8.7); y «No obstante lo dispuesto en el artículo 7, deberá proporcionarse al donante vivo asistencia sanitaria para su restablecimiento y se facilitará su seguimiento clínico en relación con la obtención del órgano» (art. 8.8).

23 Destacan Lacruz et al. (2010: 75) que se pretende salvaguardar hasta el último momento la plena libertad del donante sin coacción de tipo económico (como podría ser, en su caso, la indemnización por los perjuicios de una revocación o arrepentimiento tardío, si cupiera). 
Como puede verse, el cumplimiento de los requisitos para la obtención de órganos de donante vivo es garantizado a través de una doble actuación médica y judicial, siendo estos dos momentos sucesivos.

La LJV ha incorporado, con algunas diferencias ${ }^{24}$, esta norma reglamentaria a su texto ${ }^{25}$. Las normas procesales del Real Decreto 1723/2012 quedan derogadas con la aparición de la nueva regulación de la $\mathrm{LJV}^{26}$, y ningún reglamento podrá volver a regular la materia.

\section{REGULACIÓN DEL EXPEDIENTE JUDICIAL EN LA NUEVA LEY DE JURISDICCIÓN VOLUNTARIA}

\section{1. ÁMBITO DE APLICACIÓN}

Conforme al art. 78.1 LJV, las normas del capítulo X de su Título II (que son los arts. 78 a 80) se aplicarán "a los expedientes que tengan por objeto la constatación de la concurrencia del consentimiento libre, consciente y desinteresado del donante y demás requisitos exigidos para la extracción y trasplante de órganos de un donante vivo por la Ley 30/1979, de 27 de octubre, sobre extracción y trasplante de órganos, y las demás normas que la desarrollen».

A través del expediente de jurisdicción voluntaria, se lleva a cabo el propósito fundamental de la LETO en la modalidad de donación para trasplante en vivo: el consentimiento perfectamente consciente y absolutamente libre del donante. Cualquier duda (ignorancia, engaño, presión, etc.) pondrá en entredicho su validez y no se llevará a cabo la extracción.

Ahora bien, reparemos en el hecho de que el art. 78.1 LJV ordena que en el expediente se constate, junto con la concurrencia del consentimiento del donante, el cumplimiento de los «demás requisitos exigidos para la extracción y trasplante de órganos de un donante vivo por la Ley 30/1979, de 27 de octubre», lo que implica para el juez un detenido examen de la documentación que le es remitida por el centro hospitalario.

24 Una diferencia, y que no es menor por lo que luego se dirá, se encuentra entre el art. 8.5 del Real Decreto 1723/2012 y el art. 80.2 LJV. El término «eficazmente», contenido en la norma reglamentaria y referido a la oposición formulada por los médicos durante la comparecencia, no existe en la nueva redacción de la LJV. A juicio de Banacloche Palao, esta circunstancia dota al texto de reserva de ley (2015: 180).

26 La disposición derogatoria única de la LJV indica: «Asimismo se consideran derogadas, conforme al apartado 2 del artículo 2 del Código Civil, cuantas normas se opongan o sean incompatibles con lo dispuesto en la presente Ley». Todo lo que hay de regulación procesal en el reglamento deja de estar en vigor con la aparición de la LJV. 


\section{COMPETENCIA}

La norma de competencia es el art. 78.2: «Será competente para conocer de estos expedientes el juez de primera instancia de la localidad donde haya de realizarse la extracción o el trasplante, a elección del solicitante».

Hay que distinguir entre competencia objetiva y territorial. Ambas, según dispone el art. 16.1 LJV, son examinadas de oficio por el secretario judicial (hoy letrado de la Administración de Justicia) tras presentarse la solicitud.

\subsection{Competencia objetiva}

Desde el punto de vista de la competencia objetiva, el asunto se atribuye al juzgado de primera instancia.

No siempre ha sido así; el Real Decreto 2070/1999 declaraba como Juez competente al Juez encargado del Registro Civil de la localidad donde ha de realizarse la extracción (art. 9.4), y más remotamente también así se disponía en el art. 4 del Real Decreto 426/1980 al mencionar al «Juez encargado del Registro Civil de la localidad de que se trate».

Se ha planteado si este cambio puede producir inconvenientes de coordinación. Así, se señala ${ }^{27}$ que el encargado del Registro Civil es un solo juez en cada partido judicial, mientras que los jueces de primera instancia son varios, muchos en las grandes ciudades, y que los responsables médicos que deben intervenir en la actuación judicial suelen desear, razonablemente, coordinarse con un solo juzgado, para poder así establecer un protocolo de actuación uniforme.

Plantea la doctrina ${ }^{28}$ el caso de una actuación verdaderamente urgente, entendiendo que, fuera de las horas de audiencia del juzgado de primera instancia, le sustituirá el juez de instrucción que atienda el servicio de guardia.

\subsection{Competencia territorial}

Como señala el art. 2.2 LJV, «en los expedientes de jurisdicción voluntaria la competencia territorial vendrá fijada por el precepto correspondiente en cada caso, sin que quepa modificarla por sumisión expresa o tácita».

27 Ibáñez Molinero (2015: 2). Sugiere este autor que el inconveniente de la competencia en turno rotario de todos los jueces de primera instancia de la localidad correspondiente se solucione en la práctica mediante el establecimiento en cada partido judicial de una normativa específica de reparto de asuntos judiciales que atribuya a un solo juez de primera instancia el conocimiento de este tipo de actuaciones.

28 Así, en concreto, Liébana y Pérez (2015:329-330). 
El precepto correspondiente es, en nuestro caso, el art. 78.2. La competencia territorial depende de la elección del donante: lugar de la extracción o lugar del trasplante. Posiblemente, en la práctica esta elección viene condicionada de ordinario por razones médicas y a favor del segundo fuero ${ }^{29}$.

Cabe señalar que, según datos de la $\mathrm{ONT}^{30}$, uno de cada cuatro o cinco órganos $(22,6 \%)$ es trasplantado en otra comunidad distinta a la que se ha realizado la donación, con flujos paralelos de enfermos para tener acceso a los trasplantes que no se hacen en su Comunidad.

\section{SOLICITUD}

\subsection{Legitimación para instar el expediente}

Para tener la condición de parte en el expediente de jurisdicción voluntaria, se debe tener capacidad para ser parte y capacidad procesal. La LJV no menciona directamente estos dos presupuestos de las partes, por lo que hay que aplicar supletoriamente lo dispuesto en los arts. 6 a 9 LEC (art. 8 LJV).

Básicamente, se plantean dos casos dudosos, que requieren un examen particular: el de los menores de edad y el de quien no goza de plenas facultades mentales. Nuestro ordenamiento salvaguarda su posición excluyéndolos de la donación en vida, pero el carácter absoluto de la prohibición choca, en un dramático conflicto de intereses, con algunos supuestos en los que estas personas son las únicas que hacen viable la extracción y posterior trasplante. Analizamos cada supuesto por separado.

Como ya se ha visto al analizar el art. 4 LETO, uno de los requisitos exigidos es que el donante sea mayor de edad ${ }^{31}$. Se alinea, pues, el derecho

29 Así lo apunta Banacloche Palao (2015: 181).

30 Balance de actividad de 2015, disponible en www.msssi.es. No se distingue en el dato entre donante vivo y fallecido, por lo que suponemos que la cifra incluye a ambos.

31 El art. 8.1.a) del Real Decreto 1723/2012, reitera tal exigencia: establece que el donante vivo debe ser persona mayor, no permitiendo expresamente el art. 8.1.d) la donación de órganos de menores de edad, aún con consentimiento de sus padres o tutores.

Sigue la misma línea que sus normas reglamentarias predecesoras. Véase los arts. 2.a) del Real Decreto 426/1980 y 9.1.a) y b) del Real Decreto 2070/1999.

Algunos autores han defendido la posibilidad de que el emancipado sea donante: así, Moreno-Luque (1984:1165), entiende que «aunque la Ley no se refiere al emancipado, deberá de considerarse a éste como a un mayor de edad, puesto que una vez alcanzada la emancipación se le considera como tal, salvo para determinados actos, recogidos en el artículo 323 del Código Civil, entre los cuales no figura, desde luego, el 
español, de forma decidida, con aquellos ordenamientos que establecen una prohibición absoluta del menor como donante vivo ${ }^{32}$, frente a otros que sí permiten la donación en ciertas circunstancias ${ }^{33}$. Nuestro sistema viene, pues, a exigir, sin excepción alguna, la mayoría de edad para un acto que significa el sacrificio de la propia integridad física.

El tema es complicado y constituye una de las cuestiones más delicadas y controvertidas, siendo uno de los grandes dilemas éticos ${ }^{34}$ de la extracción y trasplante de órganos.

De hecho, en los primeros comentarios ${ }^{35}$ a la LETO ya se pone de manifiesto la necesidad de plantear otras opciones, más favorables a la donación

de la donación de órganos». Otros, en cambio, estiman que la mayoría de edad exigida por la LETO debe entenderse en sentido literal, dada la excepcional trascendencia de este tipo de donación: así, Angoitia Gorostiaga (1996:346).

32 Refieren Lacruz et al. (2010: 74) que nunca los representantes legales del menor podrían prestar consentimiento válido, que ni siquiera evitaría el carácter delictivo de la intervención, pues de acuerdo con el art. 156 del Código Penal (que expresamente considera el caso de trasplantes de órganos), si se trata de un menor o incapacitado «no será válido el consentimiento prestado por éstos ni por sus representantes legales».

33 En Portugal, la donación de órganos y tejidos no regenerables está prohibida en el caso de menores (art. 6.4, Ley 22/2007, de 29 de junio); en cambio, conforme al art. 6.5 la donación de órganos, tejidos y células regenerables se permite, cumpliéndose determinados requisitos de manera acumulativa: a) inexistencia de donante capaz compatible; b) que el receptor sea hermano o hermana del donante, y c) que la donación sea necesaria para la salvar la vida del receptor. Vemos, pues, una variedad de matices y situaciones: sobre el particular, Dias Pereira (2015: 563).

34 En la evolución de la reflexión ética, hay, al menos, otros dos momentos fundamentales: la propia admisión de la donación en vivo (inicialmente solo cabía la donación post-mortem) y la de donantes que no pertenezcan al círculo familiar (inicialmente eran familiares donante y receptor). Sobre ello, véase Dias y Patrão (2009: 26).

35 Así, Moreno-Luque (1984: 1164 y 1165) realiza las siguientes observaciones: «Ahora bien, el menor cha de ser ciertamente considerado incapaz para ser donante vivo? Desde luego, teniendo en cuenta la legislación vigente en la materia hay que responder afirmativamente. Sin embargo, parece sumamente interesante la línea mantenida por Francia. Por el Decreto de 31 de marzo de 1978, dictado para la aplicación de la Ley de 22 de diciembre de 1976 relativo a la extracción de órganos, en cuyo artículo 3 admite que el representante legal pueda prestar consentimiento en sustitución del menor donante, cuando el receptor del órgano que se pretende ceder es su hermano o hermana del mismo. Pensando en tal norma se puede manifestar que no debería impedirse que los padres o en su caso, los representantes legales del menor (padres o tutores), dieran su consentimiento en tales supuestos, si bien es cierto que para que se considere viable este asentimiento, será necesario oír al menor, así como un informe 
por menores. Sin embargo, también es verdad que hay recientes opiniones que apoyan la ilicitud de la extracción en menores ${ }^{36}$.

En el momento presente, lo cierto es que un análisis del derecho comparado en esta materia, en el ámbito del proyecto $\mathrm{EULOD}^{37}$, sigue mostrando la cuestión como dudosa: hay sistemas, como el español, de prohibición absoluta, en los que se percibe que los menores pueden no ser capaces de evaluar la situación adecuadamente y de ahí la necesidad de protegerles, evitando situaciones de presión familiar (recuérdese que muchas donaciones se realizan entre familiares); y hay otros en los que quienes son contrarios a la prohibición absoluta señalan casos en los cuales la donación de un menor es éticamente justificable, y critican que no se tome en consideración la mayor o menor madurez del menor, siendo la aproximación más correcta la de examinar de manera individual la capacidad del menor. Sigue así apareciendo el conflicto entre la integridad física del menor y el beneficio que puede proporcionar salvar la vida a otra persona.

Existen casos en el derecho español en que el principio normativamente consagrado en su día por el art. 4 LETO quiebra y se permite al menor ser donante. Señaladamente, el caso de la médula ósea, donde no existe un trasplante de órganos, sino de células que se regeneran y por razones de compatibilidad la mayoría de los donantes son hermanos del enfermo. Así, el art. 7.1.IV del Real Decreto-Ley 9/2014, por el que se establecen las normas de calidad y seguridad para la donación, la obtención, la evaluación, el procesamiento, la preservación, el almacenamiento y la distribución de células y tejidos humanos y se aprueban las normas de coordinación y funcionamiento para su uso en humanos, dispone que «no podrán obtenerse células y tejidos de personas menores de edad o de personas que por deficiencias psíquicas, enfermedad mental, incapacitación legal o cualquier otra causa, no puedan otorgar su consentimiento, salvo cuando se trate de residuos quirúrgicos o de progenitores hematopoyéticos u otros tejidos o grupos celulares reproducibles cuya indicación terapéutica sea o pueda ser vital para el receptor. En estos

médico donde se señale que la extracción del órgano en aquél no es más gravosa debido a la menor edad, que la que se da en cualquier donante mayor».

Antes de la LETO, también ya se abogaba doctrinalmente por una limitada admisión de las extracciones en menores de edad, exclusivamente si se tratara de hermanos del receptor y se contara con el consentimiento de su representante legal y la autorización judicial, y siempre que el menor no lo rechazara: véase Romeo Casabona (1979: 163).

36 Para Bañegil Espinosa (2015: 898-899), la restricción genérica de donaciones por los menores se basa en que toda donación de tejidos u órganos puede causar un daño a la salud o integridad del donante, por mínimo que sea, sin ocasionarle ningún beneficio.

37 Véase Lopp (2013b: 119). 
casos, el consentimiento será otorgado por quien ostente la representación legal». Es una admisión excepcional de la donación por menores de edad, cuyos antecedentes se encuentran en la disposición final segunda del Real Decreto 426/1980, de 22 de febrero de 1980, por el que se desarrolla la LETO ${ }^{38}$.

No perdamos de vista en este conflicto, por otro lado, la realidad de la práctica judicial. A pesar de la claridad de la prohibición, se han dado casos de donante menor de edad, en los que su representante legal ha instado el procedimiento. Este hecho es de por sí demostrativo del extraordinario dramatismo de ciertos supuestos, que hacen adoptar al Juez una decisión contra legem.

En el supuesto que da origen al Auto 785/2007, de 18 de octubre, del Juzgado de Primera Instancia núm. 17 de Sevilla ${ }^{39}$, se admitió a trámite la solicitud formulada por la madre de la menor, promoviendo expediente de jurisdicción voluntaria. Posteriormente, se exploró a la menor, informándose por la médico forense sobre la capacidad de entender y conocer de la menor, y el Ministerio Fiscal solicitó que se dictase resolución conforme a la solicitud. El Juzgado autoriza una donación de hígado que realiza una menor de edad para su hija.

El razonamiento que contiene el fundamento de derecho $2^{\circ}$ del Auto es el siguiente:

El Código Civil en su art. 271 no establece la necesidad de que el tutor precise de autorización judicial para autorizar una donación de órganos. La Ley 14/1986, de 25 de abril, General de Sanidad, en su art. 10 permite que el tutor preste el consentimiento a la intervención quirúrgica cuando no esté capacitado para ello, en cuyo caso corresponderá a las personas allegadas al incapacitado.

No obstante el silencio normativo, no puede estimarse que para el supuesto de donación de órganos baste el consentimiento del tutor, considerando que, por analogía a los supuestos de esterilización del menor, deberá ser autorizada por el Juez supliendo la falta de capacidad del mismo.

38 Es decir, apenas cuatro meses después de promulgarse la LETO, se limita para los trasplantes de médula ósea el alcance absoluto de la prohibición de su art. 4, afirmándose que «los menores de edad pueden ser donantes, previa autorización de sus padres o tutores». La excepcional autorización se fundamenta en «las características biológicas» de la médula ósea (carácter regenerable y compatibilidad entre donante y receptor). Sobre esta disposición y su discutible legalidad (en aquel momento, una norma reglamentaria autorizaba lo que prohibía la ley), véase Angoitia Gorostiaga (1996: 303304).

39 AC 2007/1884. 
Es necesario, por tanto, acudir al proceso judicial, recabar el informe de especialistas, oír en su caso a la incapaz o menor, todo ello con intervención del Ministerio Fiscal.

El Tribunal Constitucional establece «La intervención judicial», como inexcusable para que pueda otorgarse la autorización en el supuesto análogo de esterilización, constituyendo la principal garantía a la que están subordinados todos los demás exigiendo los siguientes requisitos:

1) Solicitud por parte de quienes ostenten la representación legal de la persona incapaz ante el Juez del domicilio del incapaz.

2) Exploración judicial de la persona incapaz.

3) Oír a especialistas.

4) Intervención del Ministerio Fiscal.

Requisitos que en el presente supuesto se han cumplido, constatando que la menor es plenamente consciente de los riesgos que implica la intervención y que tiene plena capacidad para entender sobre lo actuado; manifestando, con pleno entendimiento y de forma libre y consciente, su deseo de donar a su hija parte de su hígado. Procediendo, en consecuencia, integrar el consentimiento de la menor.

El razonamiento es difícil de entender y no se sostiene con la aplicación de la normativa vigente sobre extracción y trasplante de órganos. No se trata de un supuesto en que la autorización judicial suple la falta de capacidad de la menor (sustitución de juicio), aplicando analógicamente los requisitos de esterilización de menores; en realidad, lo que hay es una prohibición absoluta de que un menor sea donante, cosa muy distinta de integrar el consentimiento de la menor. Tal prohibición, que contiene la LETO y la normativa reglamentaria aplicable en aquél momento, el Real Decreto 2070/1999, impide una decisión como la contenida en este Auto. Al margen de lo cual, comprendemos y compartimos las razones humanitarias de fondo (totalmente admisibles, pues la vida del recién nacido dependía de su trasplante de hígado cuyo único donante compatible era su madre menor de edad) que mueven al juez a autorizar la donación.

El otro caso al que aludíamos es el de la persona que no presenta facultades mentales plenas, al margen de que exista o no declaración judicial de incapacitación ${ }^{40}$. Nuestro sistema establece, también aquí, una prohibición abso-

40 El no gozar de plenas facultades mentales puede o no coincidir con la incapacitación. Son imaginables variedad de situaciones. Así, tal y como describe Angoitia Gorostiaga (1996:366), cabría admitir excepcionalmente la extracción en personas que, a pesar de la declaración de incapacidad, posean suficiente grado de discernimiento para consentir válidamente aquella, posibilidad que solo parece viable cuando, conforme al art. 287 del Cógido Civil, la sentencia de incapacitación o, en su caso, la resolución que 
luta, con una formulación ciertamente amplia ${ }^{41}$. En efecto, el art. 4 b) LETO requiere "que el donante goce de plenas facultades mentales», mientras que el apartado c) de la misma norma indica que «no podrá obtenerse ningún tipo de órganos de personas que, por deficiencias psíquicas o enfermedad mental o por cualquier otra causa, no puedan otorgar su consentimiento expreso, libre y consciente», repitiéndose estas mismas exigencias en el art. 8.1 a) y d) del Real Decreto 1723/2012 ${ }^{42}$. Partiendo de la base de que el consentimiento informado de la persona es absolutamente esencial, debería descartarse como donante a quien no tenga la capacidad para prestarlo. Si no existe capacidad de discernimiento, no podría autorizarse la donación y tampoco recurrir a una sustitución de su juicio.

El proyecto EULOD busca alcanzar el consenso en esta difícil cuestión, inclinándose por la posibilidad de que sean donantes menores de edad y personas adultas con capacidad limitada ${ }^{43}$, apartándose así de los sistemas de prohibición absoluta. No se recomienda excluir el recurso a estos grupos en términos absolutos ante situaciones muy excepcionales, acompañando la extracción de los más estrictos requisitos y garantías ${ }^{44}$ : el carácter absolutamente esencial del consentimiento informado del donante; la relación personal estrecha entre potencial donante y receptor; el tipo de órgano a donar, en tanto que los riesgos asociados a la donación difieren según sea uno u otro; el carácter de ultima ratio de esta donación, y la creación de una comisión independiente que apruebe esta donación. Se asume así que no debería realizarse prohibiciones absolutas, sino dictar específicos requisitos que permitieran las donaciones en casos muy excepcionales.

la modifique, coloquen al incapacitado bajo el régimen de curatela, en atención a su grado de discernimiento.

41 Lo señala Angoitia Gorostiaga (1996:329): «[...] la extraordinaria amplitud de los términos con que parece excluirse toda posibilidad de que el donante se vea aquejado por alguna enfermedad o malestar de naturaleza psíquica o mental requiere, en mi opinión, una interpretación que limite los mismos a aquellos supuestos en que dicha deficiencia o perturbación alcance una significación trascendente o se manifieste en relación directa con el hecho de la extracción. No creo, en este sentido, que un padre afectado por un estado de angustia o depresión por razón de la grave enfermedad de su hijo pueda, por ello, ser excluido de la condición de donante del órgano o tejido cuyo trasplante puede salvar la vida de aquel».

42 El Real Decreto 1723/2012 sigue, en este punto, lo que ya establecía el art. 9.1 a) y d) del Real Decreto 2070/1999.

43 Lopp (2013b: 120) utiliza la expresión «mentally incapacitated adults», que hemos optado por no traducir literalmente.

44 Véase Lopp (2013b: 120). 
En conclusión, ni los menores ni las personas que no gocen de plenas facultades mentales pueden ser donantes en vida, si aplicamos la actual regulación española en materia de trasplantes. Otra cosa será que, en una futura reforma legislativa, se opte por una solución más matizada y favorable a su admisión, en función de las circunstancias extraordinarias que puedan concurrir en casos concretos.

\subsection{Representación y defensa}

$\mathrm{El}$ art. 79.1.II LJV dispone que "para la actuación en estos expedientes no será necesaria la intervención de abogado o procurador», lo que permite la autopostulación. Se sigue así la tónica general de no considerar preceptiva esta intervención en los procedimientos que se desarrollan ante el juez en materia de personas.

Ahora bien, el art. 3.2.I LJV prevé, con carácter general, que el interesado pueda requerir voluntariamente la intervención de abogado y procurador en aquellos casos (como el que aquí nos ocupa) en que la ley no la considera necesaria, y el coste derivado de tal actuación lo asumirá lógicamente quien la ha solicitado, dado que no cabe condena en $\operatorname{costas}^{45}$.

Existe, además, otra vía por la que se hace necesaria la intervención de abogado y procurador. El art. 3.2.II LJV dispone que «en todo caso, será necesaria la actuación de abogado y procurador para la presentación de recursos de revisión y apelación que en su caso se interpongan contra la resolución definitiva que se dicte en el expediente, así como a partir del momento en que se formule oposición».

\subsection{La iniciación del expediente: solicitud o comunicación}

Indica el art. 79.1.I LJV que «el expediente se iniciará mediante solicitud del donante o comunicación del director del centro sanitario en que vaya a efectuarse la extracción o persona en quien delegue $[\ldots] »^{46}$. La distinción en-

45 El art. 19 LJV, que regula la resolución del expediente, no señala que deba pronunciarse sobre las costas el auto o decreto que pone fin al expediente.

46 La obtención de órganos procedentes de donantes vivos para su ulterior trasplante solo podrá realizarse en los centros sanitarios expresamente autorizados por la autoridad competente de la comunidad autónoma correspondiente (art. 10.1 del Real Decreto 1723/2012). Para poder ser autorizados, los centros donde se realizan estas actividades deberán reunir, al menos, los siguientes requisitos: a) estar autorizado como centro de obtención de órganos procedentes de donantes fallecidos y como centro de trasplante del órgano para el que se solicita la autorización de obtención de donante vivo; b) 
tre «solicitud» (si lo inicia el propio donante) y «comunicación» (si lo inicia el director) no parece que tenga relevancia alguna, no siendo otra cosa que distintas maneras de denominar la incoación del procedimiento.

La LJV no impone una forma especial para esta solicitud o comunicación. Cabría por ello plantearse si puede también efectuarse por comparecencia, bien del donante, bien del director del centro sanitario en que vaya a realizarse la extracción. La respuesta, precisamente por esa ausencia de requisito formal, debe ser afirmativa ${ }^{47}$.

Respecto del contenido de la solicitud o comunicación, el art. 79.1.I LJV concreta que en ella se expresarán "las circunstancias personales y familiares del donante, el objeto de la donación, el centro sanitario en que ha de efectuarse la extracción, la identidad del médico responsable del trasplante o extracción o en el que se delegue y se acompañará el certificado médico sobre la salud mental y física del donante, emitido de conformidad con lo dispuesto en la normativa correspondiente». Es decir, se le dan al juez los elementos que le permitirán la decisión de validar o no el consentimiento prestado ${ }^{48}$.

disponer de suficiente personal médico y de enfermería con cualificación y acreditada experiencia para la correcta evaluación y selección del donante y la realización de la obtención; c) disponer de las instalaciones y materiales necesarios para la correcta realización de las obtenciones, de conformidad con los estándares aceptados en esta materia y con las mejores prácticas médicas; d) disponer de los servicios sanitarios, incluyendo laboratorios y técnicas de imagen, necesarios para garantizar el adecuado estudio preoperatorio del donante y el correcto tratamiento de las eventuales complicaciones que puedan surgir en el mismo. Estos servicios sanitarios contarán con personal cualificado y con instalaciones y equipos apropiados; e) disponer de protocolos que aseguren la adecuada evaluación y selección del donante, la transmisión de información relativa al donante y al receptor cuando la obtención y el trasplante no se efectúen en el mismo centro, el proceso de la obtención y el seguimiento postoperatorio inmediato y a largo plazo, así como otros protocolos a los que se refiere el artículo 25; f) disponer de un registro de acceso restringido y confidencial, con sus correspondientes claves alfanuméricas, donde se recogerán los datos necesarios que permitan garantizar la trazabilidad; g) garantizar el registro de la información relativa a los donantes vivos y su seguimiento clínico, de acuerdo con lo establecido en el artículo 31, sin perjuicio de las disposiciones sobre protección de datos personales y secreto estadístico, y h) cumplir con los requisitos establecidos en materia de confidencialidad y protección de datos personales, promoción y publicidad y gratuidad de las donaciones (art. 10.2 del Real Decreto 1723/2012).

47 En la doctrina se ha venido admitiendo, con respecto al Decreto 2070/1999, la solicitud efectuada por comparecencia ante el encargado del Registro Civil (González Poveda, 2008: 403).

$48 \mathrm{Al}$ respecto, Banacloche Palao (2015: 181). 
En la práctica, no hay, sin embargo, un ajuste estricto a lo que dispone el art. 79.1.I LJV cuando se inicia el expediente por comunicación del hospital. El Ministerio de Sanidad, en particular la ONT, tiene un formulario ${ }^{49}$, dirigido al juez decano, donde se le ruega que se realicen las diligencias necesarias para el reparto al juzgado de primera instancia competente y se comuniquen por este lo antes posible al hospital la siguiente información: el juzgado asignado y sus datos de contacto para el envío de la documentación completa; el lugar, día y hora de la comparecencia ante el juez del donante, del médico que ha de efectuar la extracción, del médico al que se refiere el apartado 3 del artículo 8 del Real Decreto 1723/2012, del médico responsable del trasplante o en quien este delegue, y de la persona a la que le corresponde dar la conformidad para la intervención, quedando citados a tales efectos. Como puede verse, la documentación completa no se envía con la comunicación (que es lo que prevé literalmente la LJV), sino en un momento posterior, una vez ya conocido el juzgado competente y antes de que tenga lugar el acto de la comparecencia, uniéndose a los autos por diligencia de ordenación.

Téngase, finalmente, en cuenta la posibilidad, si se insta el expediente por solicitud del propio donante, de que se utilice un impreso normalizado, que facilita la Oficina Judicial y que está previsto por el art. 14.3.I LJV para los casos en que no es preceptiva la intervención de Abogado y Procurador.

\section{ADMISIÓN DE LA SOLICITUD Y CITACIÓN DE LOS INTERESADOS}

Tras la presentación de la solicitud, el secretario judicial (hoy letrado de la Administración de Justicia) resolverá sobre la misma y, si considera que esta no resulta admisible, dará cuenta al juez, al ser de su competencia este expediente, para que acuerde lo que proceda. Así lo entendemos, siguiendo lo dispuesto en el art. 17.1 LJV. Hay que pensar en que pueden existir supuestos en los que la petición debe rechazarse ab initio, como cuando resultan incumplidos los requisitos exigidos para la donación de órganos de personas vivas.

Admitida, en cambio, la solicitud, el art. 17.2 LJV prescribe que el secretario judicial citará a una comparecencia a quienes hayan de intervenir en el expediente. El art. 79.2 LJV establece que «se citará al médico que ha de efectuar la extracción, al médico firmante del certificado a que se refiere el ar-

49 Contiene como datos: nombre y apellidos del coordinador o persona que solicita el expediente; nombre y apellidos del gerente del hospital; nombre y apellidos del donante; indicación si en la localidad donde se presenta se realiza la extracción, el trasplante, o ambos; número de fax del hospital donde se recibirán los datos e indicaciones del juzgado, y lugar y fecha. 
tículo anterior (certificado médico sobre la salud mental y física del donante), al médico responsable del trasplante o en quien delegue y a la persona a quien corresponda dar la autorización para la intervención, conforme al documento de autorización para la extracción de órganos concedida al centro sanitario de que se trate o en quien este delegue».

Se prevé, pues, la citación de hasta cuatro personas ${ }^{50}$, aunque pueden ser menos si alguno de ellos interviene en más de una condición profesional ${ }^{51}$. La redacción actual de la LJV viene a reproducir lo que ya se dice en el art. 9.4.II Real Decreto 1723/2012. En realidad, con el paso del tiempo, se han ido incrementando el número de intervinientes, pues la Ley 30/1979 solamente menciona al médico que ha de efectuar la extracción [art. 4.c)], mientras que el Real Decreto 426/1980 llama a comparecer al médico que firma el certificado sobre la salud del donante y a la persona a quien corresponde autorizar la intervención (art. 4.II) y el Real Decreto 2070/1999 añade a los anteriores al médico responsable del trasplante (art. 9.4.I), manteniéndose desde entonces este elenco de intervinientes.

Para la citación a la comparecencia habrá de observarse la norma general del art. 17.3.I LJV: «Los interesados serán citados a comparecencia con al menos quince días de antelación a su celebración, avisándoles de que deberán acudir a aquélla con los medios de prueba de que intenten valerse. La citación se practicará en la forma prevenida en la Ley de Enjuiciamiento Civil, con entrega de la copia de la resolución, de la solicitud y de los documentos que la acompañen». Puede plantearse alguna duda con relación a situaciones verdaderamente urgentes, que aconsejen prescindir del plazo de quince días; no parece correcto establecer un único criterio temporal, sin atender a la imperiosa necesidad de algún trasplante. En cualquier caso, tenemos conocimiento de algún expediente en el que no median los quince días preceptivos desde la citación a la comparecencia, lo que da idea de que la práctica judicial suele acortar el plazo.

Además del cuadro médico-hospitalario, en la comparecencia intervienen el juez, el letrado de la Administración de Justicia (que debe dar fe de lo

50 De la Iglesia Monje (2015: 231) utiliza la denominación de «cuadro médico y/u hospitalario".

51 No sería el caso del médico que certifica el estado de salud, que ha de ser distinto del que realiza la extracción y el trasplante, tal y como expresamente prescribe el art. 9.3.I del Real Decreto 1723/2012: «El estado de salud físico y mental del donante deberá ser acreditado por un médico cualificado distinto de aquéllos que vayan a efectuar la extracción y el trasplante [...]». Pero sí podría coincidir en un mismo médico la extracción y el posterior trasplante. 
actuado) y el propio donante. Cabe, no obstante, plantear otras dos posibilidades, como son las del fiscal y la del receptor del órgano.

\section{1. El Ministerio Fiscal}

En lo que respecta al Ministerio Fiscal, el art. 4 LJV prevé su intervención en procedimientos de la jurisdicción voluntaria «cuando afecten al estado civil o condición de la persona o esté comprometido el interés de un menor o una persona con capacidad modificada judicialmente, y en aquellos casos en que la ley expresamente así lo declare».

Ahora bien, de la Circular 9/2015, de 22 de diciembre, sobre la intervención del Ministerio Fiscal en la nueva Ley de Jurisdicción Voluntaria, podemos deducir que se descarta la presencia del Ministerio Público en el expediente de extracción de órganos: es, curiosamente, el único expediente de la jurisdicción voluntaria en materia de personas donde se da esto. Concretamente, se lee en dicha Circular ${ }^{52}$ los motivos de esta exclusión: «Debe reseñarse que dentro del primer grupo, no se incluye la intervención del fiscal en el expediente previsto en el capítulo X (extracción de órganos de donantes vivos). Es el único del título II en que dicha circunstancia se da. La razón radica en que se exige que el donante sea 'mayor de edad' y 'que goce de plenas facultades mentales', no pudiendo obtenerse ningún tipo de órganos de personas que 'por deficiencias psíquicas o enfermedad mental o por cualquiera otra causa, no puedan otorgar su consentimiento expreso, libre y consciente', ni de 'menores de edad, aun con el consentimiento de los padres o tutores' (arts. 4 de la Ley 30/1979, de 27 de octubre, sobre extracción y trasplante de órganos y 8 del RD 1723/2012, de 28 de diciembre, por el que se regulan las actividades de obtención, utilización clínica y coordinación territorial de los órganos humanos destinados al trasplante y se establecen requisitos de calidad y seguridad)». El argumento es claro: si no pueden ser donantes los menores ni las personas que no gocen de plenas facultades mentales, no tiene sentido citar al Ministerio Fiscal.

Por tanto, ni es un expediente tipificado en el que debe intervenir el Ministerio Fiscal, ni los supuestos del art. 4 LJV darían cobertura a su intervención ${ }^{53}$.

52 En la pág. 20.

53 A favor de la no intervención del Ministerio Fiscal se pronuncia también Ibáñez Molinero (2015: 4), con el siguiente razonamiento: «[...] con carácter general, la vieja Ley de Enjuiciamiento Civil de 1881 preveía en su artículo 1815 que se oirá al ministerio fiscal cuando la solicitud promovida afecte a los intereses públicos, y cuando se refiera 


\subsection{El receptor del órgano}

La otra situación para analizar es la del receptor del órgano. Sobre la base de que tiene un interés legítimo en el asunto y al amparo de los arts. 3 y 17 LJV, hay opiniones ${ }^{54}$ que consideran que no se le puede negar, si lo desea, ser oído en el expediente.

A mi juicio, la comparecencia sería contraria al anonimato que garantizan la LETO [art. 4.d)] y el Real Decreto 1723/2012 (art. 5). Téngase en cuenta, a este respecto, que tanto en la LETO como en el Real Decreto 1723/2012 existe la manifestación de dos declaraciones unilaterales y separadas de voluntad: la primera, referida a la extracción del órgano, y la segunda dirigida a su implantación o trasplante, siendo el propósito expreso de la normativa evitar cualquier relación entre ellas. Es clarísimo que, a pesar de llamar "donación» a la cesión de órganos, la LETO se aparta, en este punto, de la figura típica de la donación (art. 623 C.c.) al no exigir la convergencia de las dos voluntades ${ }^{55}$.

a persona o cosa cuya protección o defensa competan a la autoridad. Aunque podía estimarse que en la donación de órganos existe un interés público que justificaría la intervención del fiscal, mi criterio ya era que la falta de previsión expresa sobre su actuación en esa comparecencia no se debía a un olvido del legislador, y que por tanto no procedía convocarle ni darle audiencia. Esta postura parece más clara tras la actual redacción del artículo 4 de la nueva Ley de Jurisdicción Voluntaria, que únicamente prevé la intervención del ministerio fiscal, con carácter general en este tipo de procedimientos de jurisdicción voluntaria, "cuando afecten al estado civil o condición de la persona o esté comprometido el interés de un menor o una persona con capacidad modificada judicialmente, y en aquellos otros casos en que la ley expresamente así lo declare», sin referencia ya a ese criterio del "interés público"».

54 Así, en concreto, Ibáñez Molinero (2015: 4), que matiza lo siguiente: «Sin embargo, aunque donante y receptor comparezcan juntos en el juzgado (caso frecuente en la práctica, dada la usual relación de parentesco entre ambos), estimamos necesario que en algún momento el juez oiga al donante sin la presencia del receptor. Se trata de que el donante pueda expresarse con total libertad, manifestando sus dudas si las tuviere. Debe descartarse cualquier riesgo de que el donante actúe bajo presión, aunque simplemente sea de tipo emocional».

55 Gordillo (1987:65) lo describe en los siguientes términos: «[...] la palabra consentimiento, que la Ley emplea para referirse a la manifestación de voluntad del donante o del receptor, no es expresiva de una declaración de voluntad llamada a encontrarse con otra, constituyendo la fusión de ambas un único acto negocial; indica, por el contrario, dos voluntades separadas e independientes en su eficacia la una de la otra; la voluntad exquisitamente unilateral de ceder el órgano (consintiendo a su extracción) y la de recibir un órgano ajeno (consintiendo a su implantación)». 
Solamente cabría plantear la intervención del receptor si es una donación entre personas relacionadas genéticamente, por parentesco o por amistad íntima, caso este en el que el art. 5.2.II del Real Decreto 1723/2012 permite excepcionar la prohibición de conocer la identidad del receptor ${ }^{56}$. Ahora bien, incluso situados en este ámbito en el que se conocen donante y receptor habría motivos para descartar la intervención en el expediente, salvo que se concrete cuál es ese interés legítimo del que se habla en el art. 3 LJV. Recuérdese, a este respecto, que el documento de cesión del órgano no requiere consentimiento del receptor y la comparecencia se dirige básicamente a validar la decisión del donante ${ }^{57}$.

Otra cosa distinta sería que el Juez sospeche la existencia de presiones u ofrecimientos económicos, y quiera citar al receptor para practicar prueba sobre estos extremos ${ }^{58}$. Habría, lógicamente, que admitir esta comparecencia, sirviendo de cobertura jurídica de la misma los amplios términos del art. 17 LJV.

\section{COMPARECENCIA}

El art. 79.3 LJV perfila lo que es el objeto y desarrollo de la comparecencia: «El donante deberá otorgar su consentimiento expreso ante el juez

56 La Ley y el Reglamento insisten en que ha de garantizarse el anonimato del receptor del órgano. Ello no impide que se haga una donación de un órgano a una persona designada por el propio donante. No se ve la razón por la que ha de ser válida la donación de un riñón, por ejemplo, en favor de cualquier enfermo necesitado de él, y no en favor de un determinado amigo o pariente. Lo que la ley prohíbe es que se informe al donante de la identidad del receptor, que es distinto del supuesto en que aquel designa a la persona a quien quiere beneficiar. Al respecto, Díez-Picazo y Gullón (2012: 333-334).

Téngase en cuenta, tal y como se pone de manifiesto en los estudios del proyecto EULOD, que la donación de órganos de personas vivas está muy frecuentemente asociada con casos en los que donante y receptor están relacionados, genéticamente (padres e hijos) o emocionalmente (amigos, cónyuges), aunque no faltan los casos de tercero completamente extraño, conocidos como «buen samaritano». Al respecto, Pascalev et al. (2013: 30).

$57 \mathrm{El}$ art. 6 LETO, en su apartado c), prevé «que el receptor exprese por escrito [...] su consentimiento para la realización del trasplante [...]», pero tal consentimiento se presta, de ordinario, en sede hospitalaria, fuera del expediente de jurisdicción voluntaria.

58 Es un lugar común en la doctrina que estudia la LOD la puntual referencia a la conexión entre las relaciones donante-receptor y la ausencia de decisión voluntaria. Al respecto, Lopp (2013a: 87). 
durante la comparecencia, tras oír las explicaciones del médico que ha de efectuar la extracción y las de los demás asistentes al acto. El juez podrá asimismo requerir de estos las explicaciones que estime oportunas sobre la concurrencia de los requisitos exigidos en la ley para el otorgamiento del consentimiento».

La norma sugiere un orden de intervenciones, en línea con lo que dice el art. 4 de la LETO 59 .

En primer lugar, las explicaciones del médico que ha de efectuar la extracción y las de los demás asistentes al acto, que son el médico firmante del certificado sobre salud mental y física del donante, el médico responsable del trasplante $e^{60}$, y la persona a la que corresponde dar la autorización para la intervención. Es decir, la comparecencia se inicia con explicaciones de estos profesionales médicos, no pudiendo obviarse este trámite por el hecho de que el donante haya ya recibido información de antemano ${ }^{61}$. Se prevé, asimismo, que el juez pueda requerir de estos profesionales las explicaciones que estime oportunas sobre la concurrencia de los requisitos exigidos en la ley para el otorgamiento del consentimiento. Queda claro, pues, que intervienen en este acto a modo de peritos con la finalidad de garantizar que la emisión del consentimiento cumple con los requisitos establecidos legalmente. Es de notar que la LJV expresamente prevé en el art. 79.3 las explicaciones de todos los profesionales llamados a la comparecencia, rectificando así el criterio de las normas reglamentarias, que únicamente contemplaban las explicaciones del médico que ha de efectuar la extracción ${ }^{62}$.

En segundo lugar y tras oír las explicaciones médicas, interviene el donante, que deberá otorgar su consentimiento expreso ante el juez. La intervención del donante no debe limitarse a la manifestación del consentimiento,

59 Concretamente la letra c) indica: «Que el donante otorgue su consentimiento de forma expresa, libre y consciente, debiendo manifestarlo, por escrito, ante la autoridad pública que reglamentariamente se determine, tras la explicaciones del médico que ha de efectuar la extracción [...]». Este precepto solamente menciona al médico que ha de efectuar la extracción, mientras que la LJV tiene en cuenta explicaciones de otros profesionales. O persona en quien delegue; así, por ejemplo, cabría delegar en el jefe de servicio.

61 En realidad, el art. 79.3 LJV pretende constatar que el donante está suficientemente informado y de ahí la necesidad de dar explicaciones médicas en esta comparecencia, aunque se reitere información ya suministrada. Otra cosa distinta es que, en la práctica, los profesionales se limiten a ratificar lo que ya consta en autos (así, en concreto, el médico firmante del certificado que acredita la salud mental y física del donante).

En efecto, el Real Decreto 462/1980 (art. 4), el Real Decreto 2070/1999 (art. 9.4.I) y el Real Decreto 1723/2010 (art. 8.4.II), prevén únicamente las explicaciones del médico que efectúa la extracción. 
pudiendo, sin duda, preguntar a los profesionales médicos ${ }^{63}$. El juez, por su parte, puede, aunque nada diga la norma sobre este particular, formular preguntas al donante.

Las previsiones específicas del art. 79.3 deben ser completadas con las normas generales del art. $18 \mathrm{LJV}$ : celebración ante el juez dentro de los treinta días siguientes a la admisión de la solicitud; sustanciación por los trámites previstos en la LEC para la vista del juicio verbal con especialidades ${ }^{64}$; registro del desarrollo en soporte apto para la grabación y reproducción del sonido y de la imagen. Llamamos la atención, en particular, sobre la norma del plazo, que puede presentar inconvenientes en situaciones de verdadera urgencia.

\section{RESOLUCIÓN}

La LJV prevé dos situaciones básicas, según se extienda o no el documento de cesión de órganos.

El art. 80.1 LJV indica que «si el juez considerara que el consentimiento prestado expresamente por el donante no lo ha sido de forma libre, consciente y desinteresada, o no se cumplieran los otros requisitos establecidos legalmente, no extenderá el documento de cesión del órgano»" ${ }^{65}$.

Aunque la norma no establece expresamente la forma de la decisión denegatoria, entendemos que debe tratarse de un auto y estar motivado. Según el art. 19.1 LJV, los expedientes de competencia judicial se resuelven por medio de auto en el plazo de cinco días a contar desde la terminación de la comparecencia. El auto denegatorio puede ser recurrido, conforme a la previsión general del art. 20.2 LJV.

Adviértase, en línea con lo ya dicho al tratar del art. 78.1 LJV, que el auto denegatorio puede basarse no solamente en la falta de un consentimiento libre, consciente y desinteresado, sino también en el incumplimiento de «los otros requisitos establecidos legalmente».

La otra situación antes reseñada, que es la de extender el documento de cesión de órgano, está regulada en el art. 80.2 LJV: «En caso contrario y si

63 Es de esta opinión Banacloche Palao (2015: 181).

64 Las especialidades están reflejadas en el art. 18.2 LJV.

65 Evidentemente, como apunta Banacloche Palao (2015:182), se trata de una decisión muy grave, «y tiene que haber circunstancias objetivas que la justifiquen (generalmente relacionadas con la falta de capacidad del donante, o las presiones a que está sometido, o la inidoneidad para apreciar los riesgos que para él implica la intervención, o la sospecha de intereses espurios), porque no parece que sea razonable que el juez sustituya una decisión tal personal y arriesgada como la de la donación de un órgano tomada por el donante, por la suya propia». 
estimara que se han cumplido los requisitos legales, extenderá por escrito el documento de cesión del órgano que será firmado por el interesado, el médico que ha de efectuar la extracción y los demás asistentes».

En la práctica, cuando no hay oposición y el juez estima que se han cumplido todos los requisitos legales, el acta de la comparecencia es el documento al que la LJV llama «documento de cesión" ${ }^{66}$. Cabría plantearse si esta práctica de dar al acta de comparecencia la consideración de documento de cesión es ajustada al art. 19.1 LJV, donde imperativamente se señala que el «el expediente se resolverá por medio de auto o decreto, según corresponda la competencia al juez o al secretario judicial [...]». El hecho de dar por finalizado el expediente con el acta de comparecencia, aun cuando se la dote de la consideración de documento de cesión, parece contravenir el tenor literal de esta disposición general. Sería, por tanto, necesario concluir por medio de auto y que este tuviese la consideración de documento de cesión. Auto que pone fin al expediente y es susceptible de recurso, conforme prevé el art. 20.2 LJV.

Este mismo art. 80.2, en su parte final, dicta la siguiente disposición: «Si alguno de ellos dudara de que el consentimiento prestado haya sido de forma expresa, consciente y desinteresada, podrá oponerse a la donación».

Una de las cuestiones que plantean mayores dudas es la relativa a la oposición que menciona el art. 80.2 LJV. Curiosamente, esta posibilidad no se recogía en el Proyecto de Ley de Jurisdicción Voluntaria, publicado en el Boletin Oficial del Congreso, serie A, num. 112-1, el 5 de septiembre de 2014, a pesar de tener una larga presencia en la normativa reglamentaria de trasplante de órganos e incluso en el anterior Proyecto de Ley de Jurisdicción Voluntaria retirado en 2007.

En efecto, aparece, por primera vez, mencionada en el art. 4.II del Real Decreto 426/1980 ( El documento de cesión será firmado por el interesado y por los demás asistentes. Cualquiera de ellos podrá oponerse eficazmente a la donación y, por tanto, a la extracción de órganos del donante vivo, aunque se reúnan formalmente todos los requisitos si albergan duda sobre la manifestación del consentimiento del donante en forma expresa, libre, consciente y plenamente desinteresada») y se mantiene posteriormente en el art. 9.4.II del Real Decreto 2070/1999 ( $« \mathrm{El}$ documento de cesión donde se manifiesta la conformidad del donante será firmado por el interesado, el médico que ha de ejecutar la extracción y los demás asistentes. Cualquiera de ellos podrá oponerse eficazmente a la donación si albergan duda sobre que el consentimiento del donante se ha manifestado de forma expresa, libre, consciente y

66 Al respecto, Ibáñez Molinero (2015: 5). 
desinteresada») y en el art. 8.5 del Real Decreto 1723/2012 («El documento de cesión del órgano donde se manifiesta la conformidad del donante será extendido por el juez y firmado por el donante, el médico que ha de efectuar la extracción y los demás asistentes. Si alguno de los anteriores dudara de que el consentimiento para la obtención se hubiese otorgado de forma expresa, libre, consciente y desinteresada, podrá oponerse eficazmente a la donación»).

Con anterioridad a la LJV, la doctrina ha entendido que se trata de una oposición que se formula oralmente en el acto de la comparecencia, no exigiendo la ley que sea razonada y teniendo como efecto la imposibilidad de la prestación de consentimiento sobre la cesión de órgano ${ }^{67}$. Conviene llamar la atención sobre esto último, pues lo que viene a sostenerse es que, formulada oposición, se archive el expediente sin más trámite ${ }^{68}$.

Si comparamos la redacción actual de la LJV y la del art. 8.5 del Real Decreto 1723/2012, vemos que se ha suprimido el término "eficazmente» y esta eliminación puede querer indicar que la oposición no suspende la extracción ${ }^{69}$. También resulta útil la comparación con el art. 98.4 del Proyecto de Ley 621/000115, de Jurisdicción Voluntaria, retirado el 24 de octubre de 2007 antes de la votación de su texto por el Pleno del Senado ${ }^{70}$ : «Si en la comparecencia se formulara oposición se archivará el expediente sin más trámite». Queda claro, pues, que la oposición, en la normativa vigente, no tiene la virtualidad de poner fin al expediente. En realidad, esta solución es perfectamente coherente con lo que dispone el art. 17.3.II LJV, que constituye un cambio radical en relación con el art. 1.817 de la LEC de 1881: mientras que antes la oposición ponía fin al expediente, que se transformaba inmediatamente en contencioso, hoy, con la nueva LJV, el expediente continúa tramitándose hasta el final ${ }^{71}$.

67 González Poveda (2008: 404).

68 González Poveda (2008: 404) e Ibáñez Molinero (2015: 5).

69 Así lo entiende Banacloche Palao (2015: 182). En la misma línea, se pronuncia también Ibáñez Molinero (2015: 5).

70 BOCG. Senado. VII Legislatura. Serie II: Proyectos de Ley. 24 de julio de 2007. Num. 115 (a).

71 El art. 1.817 LEC-1881 disponía: «Si a la solicitud promovida se hiciere oposición por alguna que tenga interés en el asunto, se hará contencioso el expediente, sin alterar la situación que tuvieren, al tiempo de ser incoado, los interesados y lo que fuere objeto de él, y se sujetará a los trámites establecidos para el juicio que corresponda, según la cuantía». En una dirección distinta, el art. 17.3.II LJV: «Si alguno de los interesados fuera a formular oposición, deberá hacerlo en los cinco días siguientes a su citación, y no se hará contencioso el expediente, ni impedirá que continúe su tramitación hasta 
Pero este no es el único problema que presenta el inciso final del art. 80.2 LJV. Hay, por lo menos, dos cuestiones que merecen un detenido análisis.

Por un lado, se precisa determinar quiénes pueden albergar las dudas y formular oposición: ¿a quién señala la norma cuando dice «si alguno de ellos»? Hay que pensar que se está refiriendo a alguno de los médicos asistentes a la comparecencia, descartando que pueda serlo, por la propia lógica de las cosas, el juez o el donante. El motivo de la disconformidad puede ser la invalidez del consentimiento, por ausencia de alguno de los requisitos exigidos (claridad, libertad, conocimiento, desinterés $)^{72}$.

Por otro, y aquí las dudas son mayores, conviene averiguar la forma en que se articula procesalmente dicha oposición. Se plantean diversos interrogantes.

Una primera interpretación posible sería la de entender que los médicos se oponen a la decisión del juez a través del recurso de apelación. Conforme al art. 20.2 LJV, «las resoluciones definitivas dictadas por el juez en los expedientes de jurisdicción voluntaria podrán ser recurridas en apelación por cualquier interesado que se considere perjudicado por ella, conforme a lo dispuesto en la Ley de Enjuiciamiento Civil». Los médicos no promueven el expediente (no son solicitantes, partes originarias), pero entran posteriormente en él por la llamada del tribunal, teniendo, a nuestro juicio, la condición de interesa$\operatorname{dos}^{73}$. No debe, pues, ofrecer duda alguna su legitimación para recurrir en apelación ${ }^{74}$.

¿Puede existir oposición de los médicos antes de la resolución definitiva? La respuesta debe ser, a nuestro juicio, afirmativa. En este caso, aparecen dos escenarios:

que sea resuelto, salvo que la ley expresamente lo prevea. Del escrito de oposición se dará traslado a la parte solicitante inmediatamente».

72 Así, en concreto, Banacloche Palao (2015: 183).

73 El art. 3.1 LJV dispone lo siguiente: «Podrán promover expedientes de jurisdicción voluntaria e intervenir en ellos quienes sean titulares de derechos o intereses legítimos o cuya legitimación les venga conferida legalmente sobre la materia que constituya su objeto, sin perjuicio de los casos en que el expediente pueda iniciarse de oficio o a instancia del Ministerio Fiscal». Se distingue así entre dos tipos de sujetos: los que promueven (solicitantes) y los que intervienen (interesados), distinción que ya recogía la LEC de 1881 en el art. 1.813: «el que promoviere el acto...», «el que tenga interés legítimo en él...».

74 Está legitimado para interponer el recurso «cualquier interesado» y no solo el solicitante, siempre que esgrima un "perjuicio» (el gravamen generalmente exigido) producido por la resolución que se recurre. 
1) Una oposición a la solicitud, formulada antes de la comparecencia, donde haría falta ya la intervención de abogado y procurador (art. 3.2.II LJV) y que entraría en el supuesto previsto por el art. 17.3.II LJV: «Si alguno de los interesados fuera a formular oposición, deberá hacerlo en los cinco días siguientes a su citación, y no se hará contencioso el expediente, ni impedirá que continúe su tramitación hasta que sea resuelto, salvo que la ley expresamente lo prevea. Del escrito de oposición se dará traslado a la parte solicitante inmediatamente»; todas estas cuestiones relativas a la oposición se discutirán en la comparecencia y serán resueltas por el juez.

2) Una oposición formulada en la propia comparecencia (es decir, que no se ha formalizado con anterioridad, incumpliendo el mandato del art. 17.3.II LJV). El tema es dudoso, no solamente porque el art. 80.2.I LJV se refiere a la oposición de los profesionales con ocasión de la resolución del expediente (y no con ocasión de la comparecencia), sino porque el título preliminar de la LJV, dedicado a las disposiciones generales, no regula la oposición en el mismo acto de la comparecencia, tal y como se deduce de la lectura del art. 17.3.II LJV. Sin embargo, vemos más que posible que, en la práctica, se formulen (sin abogado ni procurador) oposiciones en el acto de comparecencia, y aquí hay dos posibilidades: tratarlas como simples alegaciones, respecto de las cuales cabe la posibilidad de ordenar de oficio la prueba correspondiente (art. 5 LJV), o bien estimar que ya no cabe de ninguna manera oposición formal en la comparecencia, basándose en una aplicación supletoria de la LEC.

Concluye el art. 80.3 LJV que «del documento de cesión, en que se hará constar la posibilidad que tiene el donante de revocar el consentimiento en cualquier momento previo a la intervención, se facilitará copia al donante».

El consentimiento resulta, pues, revocable en cualquier momento previo a la intervención.

A diferencia del art. 8.6 del Real Decreto 1723/2012, no se menciona en la LJV el plazo de espera de veinticuatro horas que, como mínimo, ha de transcurrir entre la firma del documento de cesión del órgano y la extracción del mismo ${ }^{75}$. Nos inclinamos por entender que la norma reglamentaria sigue vigente en este punto y no ha sido derogada por la nueva regulación del expediente de jurisdicción voluntaria. Así, este plazo está fuera del procedimiento y por ello mismo debería seguir manteniéndose; de hecho, en la realidad

75 El plazo ya figuraba en el art. 4.III del Real Decreto 462/1980 y también en el art. 9.5 del Real Decreto 2070/1999. 
práctica de la comparecencia vemos que el juez informa al donante que deben transcurrir al menos veinticuatro horas entre la firma del documento de cesión del órgano y la extracción del mismo.

\section{RECURSOS}

Se ha hecho ya referencia a la posibilidad ex art. 20.2 LJV de recurrir el auto, denegatorio o aprobatorio de la cesión del órgano, al hilo de la decisión del expediente. Nos remitimos al lugar correspondiente.

\section{BIBLIOGRAFÍA}

Albaladejo, M. (2009). Derecho civil I. Introducción y Parte General. Madrid: Edisofer. Angoitia Gorostiaga, V. (1996). Extracción y trasplante de órganos y tejidos humanos. Problemática jurídica. Madrid: Marcial Pons.

- (2011). Trasplante de órganos, tejidos y células. En C.M. Romeo Casabona (dir.). Enciclopedia de Bioderecho y Bioética. Tomo II. Granada: Comares.

Arroyo Urieta, G. y Fernández Sanromán, J. (1987). Aspectos médico-legales de la extracción y trasplantes de órganos. Actualidad Civil, 1871-1890.

Banacloche Palao, J. (2015). Los nuevos expedientes y procedimientos de jurisdicción voluntaria. Análisis de la Ley 15/2015, de 2 de julio. Madrid: La Ley.

Bañegil Espinosa, M. A. (2015). En V. M. Garrido de Palma (dir.). Instituciones de Derecho Privado. Tomo I. Personas. Vol. 2. Pamplona: Thomson Reuters Civitas.

De la Iglesia Monje, M. I. (2015). En J.R. Liébana Ortiz (dir.). Cuestiones Prácticas sobre la Jurisdicción Voluntaria. Pamplona: Thomson Reuters Aranzadi.

De Lora, P. (2011). Justicia y distribución de recursos. El caso de los trasplantes de órganos y tejidos. En M. Gascón Abellán, Ma del Carmen González Carrasco y J. Cantero Martínez (coords.). Derecho Sanitario y Bioética. Cuestiones actuales. Valencia: Tirant lo Blanch.

Dias Barcelos, M. y Patraõ Neves, M. (2009). Reflexão ética sobre a doação de tecidos e órgãos humanos: entre o respeito pela autonomía e a exigencia de solidaridade. Revista Portuguesa de Bioética, 7, 23-42.

Dias Pereira, A. G. (2015). Direitos dos pacientes e responsabilidade médica. Coimbra: Coimbra Editora.

Díez-Picazo, L. y Gullón Ballesteros, A. (2012). Sistema de Derecho Civil. Vol.I. Madrid: Tecnos.

Evans, M. (1997). Organs donation should not be restricted to relatives. Journal of Medical Ethics, 15, 17-20.

Ibáñez Molinero, S. (2016). La intervención del juez en la donación de órganos de donante vivo, un acto de jurisdicción voluntaria. Cuadernos de Medicina Forense, 21 (1-2), 1-5. Disponible en: http://dx.doi.org/10.4321/S1135-76062015000100011. 
González Poveda, B. (2008). La jurisdicción voluntaria. Doctrina y formularios. Pamplona: Thomson-Aranzadi.

Gordillo Cañas, A. (1987). Trasplantes de órganos: "pietas» familiar y solidaridad humana. Madrid: Civitas

Juan Sánchez, R. (2015). En M. Ortells Ramos (dir.). Derecho Procesal Civil. Pamplona: Thomson Reuters Aranzadi.

Lacruz Berdejo, J. L., et al. (2010). Elementos de Derecho Civil. I. Parte General. Volumen Segundo. Personas. Madrid: Dykinson.

Lasarte Álvarez, C. (2015). Parte General y Derecho de la Persona. Principios de Derecho Civil I. Madrid: Marcial Pons.

Lennerling, A., et al. (2013). Living Organ Donation in Europe. Clinical Praxis. En F. Ambagtsheer y W. Weimar (eds.). The EULOD Project. Living Organ Donation in Europe. Results and Recommendations. Lengerich: Pabst Science Publishers.

Liébana Ortiz, J. R. y Pérez Escalona, S. (2015). Comentarios a la Ley de Jurisdicción Voluntaria. Ley 15/2015, de 2 de julio. Pamplona: Thomson Reuters Aranzadi.

López y López, A. M. (1969). Problemas jurídicos de los trasplantes de tejidos y órganos humanos. Anuario de Derecho Civil, 1, 145-161.

Lopp, L. (2013a). Analysing the Core Normative Arguments that Dominate the Policy Arena about Necessity and Legitimacy of Legal Restrictions in Living Donor Transplantation. En F. Ambagtsheer y W. Weimar (eds.). The EULOD Project. Living Organ Donation in Europe. Results and Recommendations. Lengerich: Pabst Science Publishers.

- (2013b). Best Practice Proposal: Legal Safeguards For Living Organ Donation in Europe in Consideration of the Current National Regulations. En F. Ambagtsheer y W. Weimar (eds.). The EULOD Project. Living Organ Donation in Europe. Results and Recommendations. Lengerich: Pabst Science Publishers.

Moreno-Luque Casariego, C. (1984). Consideraciones sobre la Ley de Trasplantes de Órganos de 27 de octubre de 1979 y el Reglamento que la desarrolla de 22 de febrero de 1980. La Ley, 1, 1162-1168.

Pascalev, A., et al. (2013). Expanding Living Organ Donation in Europe: Attitudes, Barriers and Opportunities. Results from a Multi-country Focus Group Study. En F. Ambagtsheer y W. Weimar (eds.). The EULOD Project. Living Organ Donation in Europe. Results and Recommendations. Lengerich: Pabst Science Publishers.

Romeo Casabona, C. M. (1979). Los trasplantes de órganos. Informe y documentación para la reforma de la legislación española sobre trasplantes de órganos. Barcelona: Bosch.

- (1982). La Ley de trasplantes y sus repercusiones sociales. La Ley, 1982, 1, 784-792.

Ruiz Pérez, J. S. (1989). Consideraciones jurídicas sobre el trasplante de órganos. Actualidad Civil, 5, 333-350. 